TITLE:

\title{
Novel control system for blood glucose using a model predictive method(Abstract_要旨)
}

$\operatorname{AUTHOR(S):~}$

Kan, Shugen

CITATION:

Kan, Shugen. Novel control system for blood glucose using a model predictive method. 京都大学, 2003, 博士(医学)

ISSUE DATE:

2003-09-24

URL:

http://hdl.handle.net/2433/148493

RIGHT: 


\begin{tabular}{|c|c|}
\hline 氏 & "秀" \\
\hline 学 位 の種 類 & 博 士（医 \\
\hline 学 位 記 番 号 & 論医博第 1836 号 \\
\hline 学位授与の日付 & 平成 15 年 9 月 24 日 \\
\hline 学位授与の要件 & 学位規則第 4 条第 2 項該当 \\
\hline 位論文題目 & $\begin{array}{l}\text { Novel Control System for Blood Glucose Using a Model Predictive } \\
\text { Methodに関する研究 } \\
\text { (モデル予測制御を用いた新しい血糖制御) }\end{array}$ \\
\hline
\end{tabular}

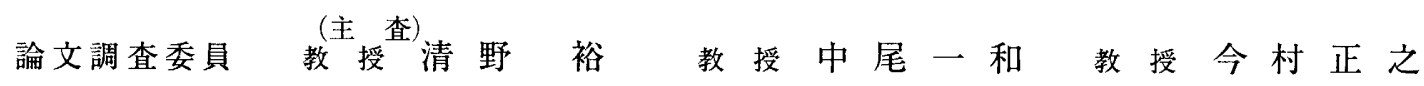

論文 内容の要旨

重症糖尿病患者の治療には，正確で安定した血糖コントロールが必須であり，とりわけ外科の周術期における血糖管理は 合併症にも直結し患者の生死をも左右する。いくつかの施設では人工膵島 STG-22（日機装社）による管理も試みられてい るが，その制御法は人間の腪分泌特性を模倣したアルゴリズムに基づく比例微分制御（PD制御）であり，実際には十分な 血糖制御ができないことも多い。申請者は, 新しい制御理論に基づく安定した血糖制御システムの開発に取り組んでいるが, 本研究では，動物実験でモデル子測制御による血糖制御を従来のPD制御と比較した。

II. 対象と方法

1. モデル予測制御の概念

このアルゴリズムは, 血糖が望ましい軌道に沿って目標值に到達するように，未来の血糖変動を予測してインスリン注入

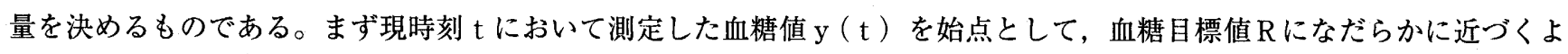
うに参照軌道 $\mathrm{y}_{\mathrm{R}}$ を決定する。次に, 過去のインスリン注入速度に基づき, 制御対象のモデルを用いて $\mathrm{y}(\mathrm{t})$ を始点とし て血糖予測值 $\mathrm{y}_{\mathrm{p}}$ 求める。そして，血糖参照軌道一致区間において血糖子測值ができるだけ参照軌道に近くなるように，現 時刻からMステップの注入速度決定区間でのインスリン注入速度を計算することを測定ごとに繰り返す方法である。

\section{2. 実験システム}

血糖制御装置は，血糖測定装置と制御装置とインスリン注入装置で構成されている。血糖測定装置はSTG-22のセンサー 部分を使用した。この装置は，静脈血中のグルコース濃度を連続的に測定することが可能であり，10秒毎にデータをコンピ ユータに送信した。制御装置にはパーソナルコンピュータを使用し，モデル予測制御を用いて計算されたインスリン注入速 度が，2 分に 1 回の割合でインスリン注入装置に指示された。グルコースの注入速度は比例制御で決定し，目標值を超えて 血糖值が低下した場合に10秒に 1 回の割合でグルコース注入装置に指示された。

\section{3. 実験対象}

$10 \mathrm{~kg}$ か $18 \mathrm{~kg}$ の 8 頭の雑種成犬に滕全摘術を施行し, 術後 3 週目以降の高血糖状態を確認し実験を行った。制御実験で は膵全摘犬に全身麻酔を行い，血糖採血ルートと補液ルートを確保した。脱水を補正し，血糖値が安定した時点で目標值を $100 \mathrm{mg} / \mathrm{dll}$ 設定して制御を行った。

III. 結果

単一のパラメータを用いた場合, モデル予測制御による血糖制御では, 平均血糖変化量が PD 制御と同程度 $(237 \mathrm{mg} / \mathrm{dl}$ 
vs. $238 \mathrm{mg} / \mathrm{dl})$ にもかかわらず，平均インスリン注入速度（ $0.75 \mathrm{mU} / \mathrm{kg} / \mathrm{min}$ vs. $1.77 \mathrm{mU} / \mathrm{kg} / \mathrm{min}, \mathrm{p}=0.004 ）$ は有意に減少し ていた。また，平均グルコース注入速度 $(0.8 \mathrm{mg} / \mathrm{kg} / \mathrm{min}$ vs. $1.3 \mathrm{mg} / \mathrm{kg} / \mathrm{min})$ は PD制御よりも少ない傾向を示した。

IV. 考察

モデル予測制御による血糖コントロールシステムでは, インスリンが各個体の血糖変化に対応し至適投与速度を計算しな がら投与されるため, 初期の過剩投与を防ぐことができ，行き過ざ量も最小限に抑えることが可能であった。そのため総 ンスリン投与量も少なくグルコースによる補償も最小に近い理想的な結果となった。過去にも，インスリンによる血糖制御 を目指した線形モデルや非線形モデルのシミュレーション報告はいくつか見られたが, いずれも臨床応用にはいたって抢 ず，申請者の今回の検討は新しい生体血糖制御法としての意義を持つものと思われる。

\section{論 女審查の結 果の 要旨}

重症糖尿病患者の治療には, 正確で安定した血糖コントロールが必須であり, とりわけ外科の周術期における血糖管理は 合併症にも直結し患者の生死をも左右する。申請者は, 新しい制御理論に基づく血糖制御システムの開発に取り組み, 11 頭 の苏全摘犬を用いてモデル予測制御による血糖制御を従来の比例微分制御と比較した。この制御理論は従来の経験則とは異 なり, 血糖を急速に目標值に合わせるのではなく, むだ時間先の変動まで予測して注入量を決め, 滑らかな軌道で目標值に 到達させるものである。モデル予測制御による血糖コントロールシステムでは, インスリンを個体の血糖変化に対応し至適 投与速度を計算して投与されたため, 初期の過剩投与を防げて, 血糖の過低下も最小限に抑えることができた。従って総 ンスリン投与量も少なくグルコース補償も最小にできて理想的な結果となった。続いてグルコース持続負荷における血楉制 御も行ったが，モデル予測制御に同定機能とゲイン調節備えた比例制御を組み込むことにより安定した血糖制御が可能とな った。以上の研究はモデル予測制御を用いた血糖制御が新しい生体血糖制御法としての意義をもち, 重症糖尿病患者や蓃切 除時の術中・術後管理において有効な手段になりうることが示唆された。

したがって，本論文は博士（医学）の学位論文として価値あるものと認める。

なお，本学位授与申請者は，平成15年 8 月 18 日実施の論文内容とそれに関連した研究分野並びに学識確認のための試問を 受け，合格と認められたものである。 